\title{
4.2 Ведення інформаційної війни як конструювання нової реальності
}

Уперше термін «інформаційна війна» вжив Томас Рон у звіті під назвою «Системи зброї та інформаційна війна» у 1976 році. Дослідник зазначає, що інформаційна сфера є невід'ємною складовою американської економіки та може бути вразливою у мирний та військовий час [113]. Саме поняття інформаційної війни (information war) почало широко застосовуватись в Америці ще з 1991 року. Але це не означає, що до цього часу світ не знав про дане явище. Можна навести декілька прикладів із Стародавньої історії, які доводять, що інформаційні війни завжди мали місце в суспільних протистояннях. Інформаційна війна це - такий спосіб подання інформації, який спрямований на дестабілізацію та сепарацію в середині суспільства. Найчастіше це відбувається прихованими методами, завдяки яким порушується колективна свідомість на психологічному рівні, що призводить до де конструкції суспільства та появи ворожої атмосфери в середині самої держави. Такий вплив здійснюються в першу чергу Засобами Масової Інформації. Грамотне ведення інформаційної війни дає можливість сформувати серед людей вигідну точку зору, систему поглядів чи навіть цілий світогляд. Адже за своєю природою індивід постійно перебуває в процесі пізнання. Тож така маніпуляція правдою, дає можливість дестабілізувати ситуацію ворога, розпалити внутрішньо державний конфлікт, особливо в сучасному світі. Будь які ЗМI передбачають в першу чергу комунікацію групи людей між собою. Поширення в маси правди, що має місце на суспільному, політичному чи світовому рівнях. Проте, з ходом еволюції суспільство навчились використовувати іï у вигідних цілях, що не завжди $є$ позитивним. Тобто, з початком глобалізації світу, усі інформації процеси стали надто неоднозначними. Через це, громадянину важко самостійно осмислювати, фільтрувати та систематизувати отриману інформацію. Тож в сучасному світі інформація прирівнюється до зброї, а вміння подати іiі у вигідному світлі - 3 мистецтвом ведення війни. 
Власне зомбування, яке виникло на зламі XX-XXI століть стало досить небезпечним явищем. Десятки років тому телебачення стало елементом повсякденності, без якого й не проходило дня у звичайного громадянина. Лише 3 появою Глобальної Мережі Інтернет, телебачення відійшло на задній план. Люди вірять усьому, що бачать на екрані свого телевізора. Вірять різним провокаціям з боку реклами чи телевізійного продукту. Суспільство стало настільки «чутливим», що контент телебачення легко може вороже налаштувати один народ проти іншого, посіяти егоїзм, розпорошити межі моральності. Найнебезпечніше - видавати брехню за правду і навпаки, шляхом підтасовки фактів, вириванням слів із контексту, посиланням до невідомого авторитету, що призвело до певного наслідування подій, що транслюють з боку користувачів медіа продукту [111, с. 402-404].

Часто маніпуляція ЗМІ спрямована не тільки проти країни суперника, але й використовуються владою задля впливу на власний народ. Сучасні політики давно усвідомили всю потужність медіа, тому й намагаються всіма силами переманити їх на свою сторону. Щоб заробити авторитет серед громадян, необхідно вміло маскувати свої недоліки, та висвітлювати власні переваги. Навіть, якщо доведеться перебільшити їх. Така «звітність» перед громадою здатна справити враження, створити певний образ та імідж того, кому це потрібно, і хто готовий за це заплатити. Наприклад, активне поширення інформації владою Росії про громадянську братовбивчу війну в Україні. I поширення серед населення того факту, що керівництво Кремля працює задля збереження народного спокою та не допущення національного конфлікту в середині держави. Таким чином, створюється ілюзія громадян про совісних політиків які працюють на благо країни. Всі кардинальні рішення влади приймаються задля безпеки громадян. I російський народ покірно $з$ цим погоджується, і не проявляє сильного інтересу до політичних рішень. Адже сутність людини полягає в потребі бути залученим до чогось, відчувати власну важливість. Саме емоції та психологічний аспект являють одним із найголовніших факторів впливу ЗMI, перед яким індивід постає майже 
беззахисним. Наприклад, агітація політиків перед виборами. Відбувається активна апеляція політика до особистості - «твій голос важливий», «ти сам обираєш своє майбутнє», «саме ти обираєш владу», « ти втомився жити в бідності - тому проголосуй і зміни ситуацію» і тому подібне. Таке спонукання до дій та активної громадянської позиції викликає певні емоції, якими людина керується при здійсненні політичного вибору. Отже, поняття «інформаційної війни» є набагато глибшим, ніж може здаватись на перший погляд. Оскільки мова йде про безліч технік, методів та різновидів прихованих впливів, під загрозою перебуває вся Світова спільнота. Існують мільйони людей які уявлення не мають про маніпуляції з боку ЗМІ, а є такі, які вміло ними користуються . Таким чином, створюється інший вимір, в якому розпорошується межа між реальним і віртуальним. Інформаційна війна не характеризується руйнуванням виключно інформаційного поля, вона несе і фізичну загрозу для держави. Зміна політичного клімату може вести за собою повстання як ворога, так і власного народу. Очевидно , що в сучасному світі виявлення суспільного невдоволення у вигляді страйків та протестів є звичним для керівництва країни. Дане явище чітко спостерігається як на прикладі України, так і сусідніх країн. Відтак, потрібно детальніше дослідити феномен гібридної війни, яка вражає як інформаційний , так і фізичний простір країни.

Гібридна війна стала одним із основних методом боротьби між державами. В першу чергу, вона покликана для послаблення когнітивних здібностей громадян та нав'язування вигідної точки зору, і як кінцевий результат абсолютне знищення державності. Визначення «гібридна війна» вперше було застосовано на саміті НАТО у Великобританії у вересні 2013 року. Воно характеризувалось як сукупність таємних бойових та інформаційних дій, здійснюваних злочинними угрупуваннями. Гібридна війна виходить за межі традиційного способу ведення війни та містить в собі низку інших явищ. Це не збройний конфлікт, а сукупність політичних інтриг, боротьба за домінування на всесвітньо-політичній арені. Росія бореться за можливість керувати політичноекономічними процесами в Україні, а також іï територією, торгівлею та 
соціокультурним середовищем. Якщо розглядати гібридну війну крізь призму військового конфлікту, то в Росії були створені цілі підрозділи збройних угрупувань, терористів, бойовиків та найманців, які оснащені найновішою зброєю та амуніцією. В поєднанні з інформаційним впливом, створюється потужний військовий сегмент, який застосовується для експансії іншої держави.

Можна виокремити основні принципи гібридної війни Росії проти України:

- ерешкоджання євроінтеграції України. Протидія співпраці з НАТО.

- здійснення заходів щодо послаблення економіки, сприяння внутрішньополітичній кризі України.

- повне підпорядкування України Російською Федерацією 3 метою реінтеграції до пострадянських структур.

- перешкоджання демократичних проявів в середині Росії, притаманних українському суспільству.

Потрібно визнати, що в добу глобалізації саме ЗМІ стали тим фактором, який конструює реальність, формує світогляд не лише особистий, але й національний. Сила медіа охоплює абсолютно усі сфери життедіяльності. Зникли межі приватності та публічності. 3 ходом еволюції інформація стала певним видом зброї, яка здатна впливати на політику, економіку, соціум як в світовому масштабі так і в середині країни. Здебільшого, це роками напрацьована система дій, де одна країна намагається контролювати соціально-політичне становище в іншій, за допомогою проплачених 3МI, у вигідних для неї цілях [112].

Агресія Російської Федерація проти України полягає в наступних діях:

- знищення інфраструктури та секторів промисловості через бойові дії, що завдає колосальний удар по економіці країни. ( Наприклад - руйнування Донецького міжнародного аеропорту)

- згубний інформаційний вплив Росії на український медіа простір.

- погіршення державного іміджу України на міжнародній політичній арені.

- перешкоджання зміцненню політичних інституцій, органів влади, держаної системи. 
- дискредитація України в проєвропейському та демократичному напрямку. Замилювання очей російському населенню 3 метою недопущення повстань.

- погіршення відносин України з іншими країнами світу.

- поступове загарбання українських територій та підпорядкування їх Російській Федерації. (Крим, Донецьк, Луганськ).

Основним завданням російської агресії є підірвати авторитет Свропи, Європейських цінностей, спотворення громадської думки, експансія держав та територій. Країна агресор різними способами перешкоджає будь який проєвропейський рух прилеглим до неї країнам ( Україна, Грузія). Так Росія намагається продемонструвати власні сили, залякати сусідні країни, деморалізувати людські цінності. Відтак, протягом останніх років стали частішими так звані «військові навчання» біля кордонів сусідніх країн, де активно демонструється повітряні та сухопутні збройні сили РФ. Це можна розцінювати як певного роду провокацію як інших держав, так і НАТО. Відомо, що з початку Незалежності України, ведеться гібридна війна з боку Росії. Проте, з настанням 2014 року, ситуація набирає все більших обертів, і як результат Революція Гідності, яка переросла в повномасштабну війну на Сході країни. Воєнний конфлікт триває вже 6 років, і з цього часу було прийнято велику кількість законів, проведено безліч переговорів, укладено мирні договори, які так і допомогли завершити війну або стабілізувати ситуацію.

На той час, в нашій державі не було дієздатного війська, належного його забезпечення та фінансування. Це стало перевагою для Російської Федерації, яка постійно нарощує сили, вкладає колосальні суми в розвиток армії та військової техніки. Варто визнати, що російський політико-економічний потенціал $\epsilon$ потужнішим за український. Саме це дало можливість агресору домінувати у веденні війни. Оскільки відомо, що військові дії - це в першу чергу витрати державних активів.

У постреволюційний період 2014 року в Україні були силові структури які могли моніторити інформаційний простір та проведення спецоперацій з боку 
Росії, проте в силу переорієнтації державних структур, все це функціонувало на примітивному рівні. Провокації на Сході давно перестали бути простим конфліктом, натомість перетворились в широкомасштабну війну, яка несе загрозу вже не тільки для України, але й як мінімум для Європи, СС надав підтримку для України. 10 червня 2015 року Свропарламент ухвалив Резолюцію «Про відносини між ЄС і Росією», де акцентується увага на тому, що Росія перестає бути їхнім стратегічним партнером. Відтак, Брюссель прийняв важливі рішення політичного, інформаційного, організаційного характеру з метою послабити натиск Росії. У липні 2016 року високопосадовці ЄС підписали 3 Генсеком НАТО декларацію про співпрацю та протидію «гібридному» впливу. 6 грудня 2016 року на саміті міністрів закордонних справ НАТО прийнято рішення про створення у 2017 році Європейського Центру протидії гібридним загрозам, також створений відповідний комплекс заходів зміцнення співпраці НATO і ЄС. Таким чином, було визнано той факт, що Російська Федерація $€$ країною-агресором та несе загрозу світового рівня [113].

Тривалий час, значна кількість російського медіа продукту була присутньою на українському телебаченні. Навіть український медіа контент транслювався російською мовою. Це призводить до популяризації російської мови та витіснення української. Проте, це стало лише початком катастрофи. Таким чином, готувався про надання статусу російській мові як державній та ще ціла низка інших негативних наслідків. Власне зомбування, яке виникло на зламі XX$\mathrm{XXI}$ століть стало досить небезпечним явищем. Десятки років тому телебачення стало елементом повсякденності, без якого не проходило й дня у звичайного громадянина. Лише з появою Глобальної Мережі Інтернет, телебачення відійшло на задній план. Люди довіряють всьому, що бачать на екрані свого телевізора.

Разом $з$ тим, настає криза медіа культури, оскільки суспільство все більше надає перевагу кількості інформації , а не якості. Адже, з психологічної точки зору , будучи в курсі подій, людина відчуває себе приналежною до чогось, що $є$ дуже важливим для неї. Так створюється «ефект присутності» - один із найпотужніших методів впливу та подання хибної інформації. Велике значення 
має те, як подається та чи інша інформація. Часто, задля досягнення максимального результату, потрібно проробити колосальну роботу, яка може тривати роками. Як приклад, можна навести «дружні» стосунки між Росією та Україною. Адже до 2014 року, як в Росії, так і в Україні активно пропагувалося те, що ми є братським народом з єдиною історією.

Сприйняття світу людством частково залежить від того, як його подають медіа. Поданий матеріал не перевіряється належним чином, це означає, що відповідальність 3МІ не є до кінця усвідомленою. Вплив медіа залишається не до кінця вивченим оскільки розвиток інформації, яка ототожнюється із знанням не можливо передбачити. А будь яка інтерпретація події є суб’єктивною i певною мірою нав'язує бачення автора. Отже, незалежно від обставин, потрібно зберігати автономію.

Соціальні мережі відіграють одну із ключових ролей повноцінного функціонування особистості у сучасному суспільстві:

- соцмережі сприяють збагаченню людей різним міжкультурним досвідом за допомогою споживання медіаповідомлень усіх типів (друкованого слова, зображень, аудіо та рухомих зображень).

- у країнах, що застосовують новітні технології, соціальні мережі допомагають громадянам представляти їхні інтереси, культуру та традиції на міжнародному рівні.

- соціальна мережа створює додаткові можливості людям у будь-якому суспільстві та уможливлює доступ до медіа людям з особливими потребами або економічно неспроможним верствам населення.

- соцмережі відіграють найважливішу роль у здатності людей оцінювати й реагувати на інформацію про соціальні та політичні конфлікти, війни, природні лиха, екологічні катастрофи тощо.

- соцмережі забезпечують миттєве розповсюдження інформації у всіх куточках світу, і відповідну миттєву реакцію громадян щодо подій, які відбулись. Тож вироблення критичного мислення детермінує всі сфери комунікації та робить доступними для людей принципи її роботи. 
Отже, інформаційні процеси є вирішальними на шляху побудови соціальнополітичних зв'язків. Саме тому, потрібно прискіпливо ставитись до усього, що публікується та виходить на всезагальний огляд. Оскільки в сучасному суспільстві інформація прирівнюється до знання, потрібно детальніше розібратися в іiі правдивості чи хибності. Захист інформації став однією 3 найбільших проблем XXI століття. Сукупність важливих даних про громадські, інфраструктурні, економічні та політичні ресурси стали зброєю в руках ворога, тому потребують належної протекції. Інформаційні процеси перетворились на потужний ресурс та стали інструментом в руках високопосадовців. У першу чергу, це пов'язано з впливом ЗМІ на психіку сучасної людини. Наплив інформації посилює відчуття вразливості та нестабільності в індивіда. Адже мозок людини не здатний сприймати та систематизувати весь потік знаків, символів чи образів, які продукують ЗМІ. Пересічний громадянин користується готовим набором інформації, його не хвилює достовірність знання, різко сприймає аргументовану критику. Так само можна охарактеризувати суспільство - воно не замислюється над своїм існуванням. 3 боку соціуму йде постійне нав'язування стереотипів та установок. Проблема кібернетичної безпеки стала широкомасштабною тоді, коли країни світу усвідомили можливі наслідки, що першочергово впливають на комп'ютерні системи. Таким чином через незначні зусилля можна паралізувати роботу усього державного апарату. Новітні технології застосовуються для автоматизації систем управління, створення цифрових державних ресурсів щодо діяльності міністерств, збереження інформації про органи виконавчої влади. Тому потрібен захист цих відомостей від несанкціонованого доступу до неї та її спотворення. Метою такого захисту $є$ зменшення інформаційного впливу на державні системи управління. 